\title{
Application of Various Teaching Methods in Building Construction Technology in Vocational and Technical Colleges
}

\author{
Xiujuan $\mathrm{Lv}^{1, *}$, Wuxin Chen ${ }^{2}$ \\ ${ }^{1}$ Department of Civil Engineering, Henan Technical College of Construction, Zhengzhou, China \\ ${ }^{2}$ College of Engineering and Architecture, Henan University of Technology, Zhengzhou, China \\ *Corresponding author. Email: 1851396013@qq.com
}

\begin{abstract}
A variety of teaching methods reflects the thoughts of teaching students in accordance with their aptitude. In order to realize training objective of Vocational and Technical Colleges, we apply a variety of teaching methods in curriculum development of Building construction technology. And we have achieved better teaching effectiveness for many years of teaching practice. We sum it up to make it perfect and wish it will be helpful to other teachers.
\end{abstract}

Keywords: A variety of teaching methods, Teach students in accordance with their aptitude, Building construction technology, New training mode.

\section{INTRODUCTION}

More than two thousand and five hundred years ago, Confucius, the sage, had infiltrated the method of "teaching students according to their aptitude" into education. Confucius has "three thousand disciples and seventy-two sages". On reflection, each "disciple" has different talents, growing environment and habits. Therefore, facing different people, his teaching methods are different from person to person. "Various teaching methods" reflects the teaching concept of "teaching students according to their aptitude". In other words, "various teaching methods" is existing in ancient times.

Through reference to materials, "multiple teaching methods" are widely used in medicine, English, mathematics, Chinese, physics, early childhood education and so on, but the research on multiple teaching methods of "construction technology" course in higher vocational colleges is relatively less.

In April 2005, he presided over the vocational education teaching reform project - "Research and Practice on improving the teaching effect of" building construction technology "by using a variety of teaching methods". In September 2007, I won the first prize of vocational education achievement of Henan Provincial Department of education. For more than ten years, I have been practicing and improving a variety of teaching methods in the teaching process, and achieved good teaching results.

In 2016, he participated in the course construction of "construction technology" in the teaching and Research Office of architectural engineering technology, an excellent grass-roots teaching organization of colleges and universities in Henan Province. And the resource base construction of XM-1 backbone professional construction project of Henan Higher Vocational Education Innovation and development action plan "construction engineering technology". In August 2017, I presided over the school level "construction technology" online open course.

\section{CHARACTERISTICS OF CONSTRUCTION TECHNOLOGY}

"Construction technology" is the core course of Civil Engineering Vocational College. It has the following characteristics:

\subsection{Practicality}

The course of construction technology itself is the summary of engineering construction practice. The main content of the course is mainly aimed at the type of work, construction technology, construction method and actual operation process of the project, which is highly practical. 


\subsection{Comprehensive}

The theoretical knowledge contained in the course involves the discipline knowledge of "building mechanics", "engineering survey", "building materials", "building structure", "foundation", etc., which is highly comprehensive.

\subsection{Independence and Large Theoretical Span}

The contents of earthwork, foundation engineering, concrete engineering, installation engineering, decoration engineering and other chapters in the construction technology course only introduce the construction technology and construction method of this type of work. Therefore, each chapter is relatively independent and has its own characteristics.

The course of "construction technology" is practical, comprehensive and practical, while the contents of each part are relatively independent, not strongly correlated and the theoretical span is large. For the sake of safety and construction progress, students are not welcome to visit the site. Therefore, students have limited access to the construction site, so the learning effect is often poor. Therefore, it is necessary to discuss the teaching reform of "construction technology".

\section{APPLICATION OF VARIOUS TEACHING METHODS IN "CONSTRUCTION TECHNOLOGY" OF HIGHER VOCATIONAL COLLEGES}

\subsection{The Traditional Teaching Method}

Traditional teaching method is teaching by blackboard in the classroom.

\subsection{Multimedia Teaching Methods}

Such as slide show, projection, recording and video recording, are also called multimedia combined teaching or audio-visual teaching.

\subsection{Heuristic Teaching Method}

"Enlighten" in heuristic teaching method comes from the Analects of Confucius. Heuristic teaching is a teaching method that teachers guide students to master knowledge actively and consciously according to the objective law of learning process.

For example, when it comes to reinforcement engineering, the "steel plate" is the ID card of the steel bar. Can you find the place of birth (place of origin) of the steel bar from the steel bar sign? Date of birth (date of birth)? Height (fixed length of reinforcement)? Weight (weight of reinforcement)? How many brothers and sisters (number of bars in a bundle)? Who witnessed its qualification (quality inspector information)? After these questions are put forward, the students are eager to answer them and stimulate their interest in learning.

\subsection{Project Teaching Method}

Project teaching method is a teaching activity that teachers and students carry out a complete project work together. "Give you 55 minutes. Can you build a bridge?" 55 minutes bridge building is a project.

\subsection{Practical Training Teaching Method}

Practical training is an important way to cultivate and improve the ability of technology application, and also the only way to achieve "zero distance" to work. It has a very important position in higher vocational education, and the practice training base is an important guarantee for the implementation of practice training teaching objectives.

\subsection{The on-site Teaching Method}

The on-site teaching method is to conduct visit, study, operation skill training, etc. in the front line of construction and production.

\subsection{Special Lecture in the Teaching of "construction technology"}

We can regularly invite well-known experts and scholars, engineering technicians with rich working experience, etc. to hold special lectures, mainly on advanced construction technology, methods, processes, new materials, new structures, etc. at home and abroad, mainly to make students understand the latest knowledge in modern construction.

After more than 12 years of exploration, we have adopted a variety of teaching methods in the course of building construction technology, which has achieved gratifying teaching results and won the favor of students.

In the specific teaching process, multimedia teaching can be used, but not necessarily every class, after making a unified slide show. How to use it depends on the content of the course. For the calculation of steel cutting and concrete mix proportion that students must master, it is recommended to use the teaching method of teaching and practice. For key points or difficult construction points, it is recommended to grasp the logical sequence and adopt the method of inspiration and inquiry. Students should be guided to accept and master easily and happily. It will make students feel interesting and practical to compile case teaching materials in detail and to explain cases properly in class. However, case teaching must conform to the content of the class and be closely linked with the reality. If there is plenty of time in the classroom, teachers can use discussion method. Although students have 
different views on discussion, and more students participate in the discussion, it will take time, but it can improve students' ability of independent thinking, active learning and eloquence. The on-the-spot teaching method is the supplement of classroom teaching. If the teacher instructs well, the students can further broaden their knowledge vision and learn what they can't learn in the classroom. In addition, teachers can also guide students to search for information about new materials and technologies through books and networks, expand their horizons and expand their knowledge.

\section{APPLICATION OF VARIOUS TEACHING METHODS IN EACH CHAPTER OF BUILDING CONSTRUCTION TECHNOLOGY}

The questionnaire was designed, and the participants were three classes of 2005 grade higher vocational college of construction engineering technology major. 127 valid questionnaires were collected. Through comprehensive analysis of the questionnaire, various teaching methods recommended in each chapter of the course "construction technology" were obtained.

\begin{tabular}{|c|c|}
\hline Contents of each chapter & Recommended teaching methods \\
\hline \multicolumn{2}{|c|}{ Chapter 1 Earthworks Construction } \\
\hline 1.1 Overview & \multirow{2}{*}{ Traditional teaching method + heuristic teaching } \\
\hline 1.2 Earthwork calculation and earthwork allocation & \\
\hline 1.3Construction preparation and auxiliary work & $\begin{array}{l}\text { Multimedia teaching }+ \text { construction animation (simulated well point } \\
\text { pipe laying and working principle) }\end{array}$ \\
\hline 1.4 Mechanized earthwork construction & $\begin{array}{l}\text { Traditional practice + Construction pictures of various earthwork } \\
\text { mechanization }+ \text { animation of front shovel, backhoe, dragline, grab } \\
\text { shovel and bulldozer construction + Video }\end{array}$ \\
\hline 1.5 Filling and compaction of earthwork & Traditional teaching method + heuristic teaching \\
\hline \multicolumn{2}{|c|}{ Chapter 2 Foundation Treatment and Foundation Engineering } \\
\hline 2.1 Foundation Treatment and reinforcement & \multirow{3}{*}{$\begin{array}{l}\text { Traditional teaching method + Construction Video + courseware + } \\
\text { animation }\end{array}$} \\
\hline $\begin{array}{l}\text { 2.2 Construction of shallow embedded reinforced } \\
\text { concrete foundation }\end{array}$ & \\
\hline 2.3 Pile foundation engineering & \\
\hline \multicolumn{2}{|c|}{ Chapter3 Masonry Works } \\
\hline 3.1 Scaffold and vertical transportation facilities & \multirow{4}{*}{$\begin{array}{l}\text { Multimedia + construction picture + Construction Video + lecture + } \\
\text { heuristic teaching + one week practice }+ \text { site visit }\end{array}$} \\
\hline 3.2 Material preparation for masonry & \\
\hline 3.3 Masonry works & \\
\hline 3.4 Quality and safety technology of masonry works & \\
\hline \multicolumn{2}{|c|}{ Chapter 4 Concrete Structure Engineering } \\
\hline 4.1 Reinforcement works & $\begin{array}{l}\text { Ttraditional training (calculation of steel cutting length) + construction } \\
\text { animation (steel connection) + Construction Video + one week steel } \\
\text { work practice training }+ \text { project teaching method (curriculum design: } \\
\text { preparation of steel cutting list) + model production (see picture) }\end{array}$ \\
\hline 4.2 Formwork & $\begin{array}{l}\text { Traditional Speaking and practicing type (formwork splicing } \\
\text { calculation) }+ \text { construction picture (common types of formwork) }+ \\
\text { practice training + site visit + model making (see picture) }\end{array}$ \\
\hline 4.3 Concrete works & $\begin{array}{l}\text { Traditional practice method (concrete mix proportion calculation) }+ \\
\text { concrete pouring construction video }+ \text { construction picture }\end{array}$ \\
\hline 4.4 Concrete prefabricated components & $\begin{array}{l}\text { Picture of traditional speaking type }+ \text { common reinforced concrete } \\
\text { prefabricated components }\end{array}$ \\
\hline $\begin{array}{l}4.5 \text { Safety technology of concrete structure } \\
\text { construction }\end{array}$ & Traditional teaching method + heuristic teaching \\
\hline \multicolumn{2}{|c|}{ Chapter5 Prestressed Concrete Works } \\
\hline 5.1 Pretension & \multirow{2}{*}{$\begin{array}{l}\text { Traditional teaching method + construction animation of pre / post } \\
\text { tensioning method + heuristic teaching + Construction Video }\end{array}$} \\
\hline 5.2 Post expansion method & \\
\hline 5.3 Construction technology of Unbonded Prestress & \multirow[b]{2}{*}{ Traditional teaching method + heuristic teaching method } \\
\hline $\begin{array}{l}5.4 \text { Prestressed concrete construction quality } \\
\text { inspection and measures }\end{array}$ & \\
\hline \multicolumn{2}{|c|}{ Chapter 6 Structural Installation Works } \\
\hline 6.1 Rigging equipment & \multirow[t]{4}{*}{ Pictures of lecturing type + common rigging equipment } \\
\hline 6.2 Hoisting machinery & \\
\hline 6.3 Installation of single floor industrial plant & \\
\hline $\begin{array}{l}\text { 6.4 Installation of single-layer industrial plant with } \\
\text { steel structure }\end{array}$ & \\
\hline
\end{tabular}




\begin{tabular}{|c|c|}
\hline 6.5 Structural installation of multistory buildings & \\
\hline $\begin{array}{l}\text { 6.6 Quality requirements and safety measures of } \\
\text { structural installation engineering }\end{array}$ & Speaking and practicing + picture + construction animation + Video \\
\hline \multicolumn{2}{|c|}{ Chapter 7 Roof and Waterproof Works } \\
\hline 7. 1Roof waterproof works & \multirow{3}{*}{$\begin{array}{l}\text { Speaking and practicing }+ \text { construction picture }+ \text { construction } \\
\text { animation }\end{array}$} \\
\hline 7. 2 Underground waterproof works & \\
\hline 7.3 Waterproof works for other indoor parts & \\
\hline \multicolumn{2}{|c|}{ Chapter8 Decoration Works } \\
\hline 8.2 Finishing works & \multirow{3}{*}{ Multimedia + construction picture + Construction Video } \\
\hline $\begin{array}{l}\text { 8.3 Floor Works } 8.4 \text { Ceiling and partition } \\
\text { works }\end{array}$ & \\
\hline $\begin{array}{l}\text { 8.5 Coating and brushing Works } 8.6 \text { Door and } \\
\text { window works }\end{array}$ & \\
\hline
\end{tabular}

\section{CONCLUSION}

In order to improve the teaching effect of "construction technology" course by various teaching means, there are certain requirements for teaching schedule, multimedia teaching equipment, digital video equipment, photographic equipment, etc. in addition to higher requirements for teachers. In the specific implementation process, we should be flexible, gradually improve in the process of "finding and solving problems", and strive for the best teaching effect.

The innovation points of this research are summarized as follows:

\subsection{Diversity of Teaching Forms}

The traditional construction course only depends on textbooks and teachers' explanation, and adopts the methods of heuristic teaching, multimedia teaching and practice training to diversify the teaching forms.

\subsection{Expansion of Teaching Capacity}

The teaching content added color pictures, made construction animations, set up complete construction videos, and practice and training links, so that the boring course content was presented in front of students in the form of three-dimensional, vivid combination of shadow, sound and material object;

\subsection{Mediation of Teaching Atmosphere}

It emphasizes the interaction between teachers and students, so that students can really participate in the classroom; it also carries out the corresponding "masonry engineering" practice training, which combines the construction theory with the construction practice, and strengthens the teaching effect.

\section{ACKNOWLEDGMENTS}

Fund Project: 1. Vocational education teaching project of Henan Education Department "research and Practice on improving the teaching effect of building construction technology by various teaching means" (2005-zjc05079), master of project 2. XM-1 backbone professional construction project of Henan Higher Vocational Education Innovation and development action plan -- construction engineering technology, leading person

\section{REFERENCES}

[1] Fu Huaxia. Construction of professional skills courses of construction engineering construction technology in Higher Vocational Colleges [J]. Building materials and decoration. February 2017: 170

[2] Lu Yanxia. Evaluation reform and time of "construction technology" course in Higher Vocational Colleges [J]. Science and technology innovation guide. 2016 (24): 136-137

[3] Liu Ping. Application and practice of various teaching methods in the course of construction technology [J]. Education and teaching forum, 2014, issue 21

[4] Lv Xiujuan, Chen Wuxin. Research and practice of application of various teaching methods in the course of construction technology [J]. Henan building materials, 2008 (1): 14-15

[5] Chen Wuxin, Lv Xiujuan. Application of heuristic teaching in the teaching of civil engineering construction [J]. Journal of natural science, Xiangtan University, 2005, (27): 65-67. 